Revista Brasil. Bot., V.31, n.3, p.425-431, jul.-set. 2008

\title{
Polyphenolic cells and their interrelation with cotyledon cells in seven species of Theobroma (Sterculiaceae)
}

\author{
MARIA HELENA MARTINI ${ }^{1,4}$, ANTONIO FIGUEIRA ${ }^{2}$, CAMILA GONÇALVES LENCI ${ }^{3}$ and \\ DÉBORA DE QUEIROZ TAVARES ${ }^{3}$
}

(received: May 17, 2007; accepted: June 12, 2008)

\begin{abstract}
Polyphenolic cells and their interrelation with cotyledon cells in seven species of Theobroma (Sterculiaceae)). The amount of cotyledon polyphenolic cells varies extensively within the Theobroma species. The polyphenolic compounds of these cells play a protective role and furthermore have an important function in the development of chocolate flavour. The morphology of the polyphenolic cells of the mesophyll is described and the development of these idioblasts in Theobroma cacao L., T. subincanum Mart., T. obovatum Klotzsch ex Bernoulli, T. grandiflorum (Willd. ex Spreng.) K. Schum., T. microcarpum Mart., T. bicolor Bonpl. and T. speciosum Willd. ex Spreng analysed. The total polyphenolic content in the seeds as determined by spectrophotometry showed a variation of about forty times. The alive, transparent polyphenolic cells are scattered throughout the cotiledonary mesophyll. However the polyphenolic cells of $T$. cacao and $T$. grandiflorum are also aligned perpendicularly with respect to the mesophyll borders and, in addition, both species display polyphenolic cells with a natural translucent purple colour. All the species analysed contained polyphenolic cells scattered throughout the parenchymal cells and also in a lengthwise association with vascular bundles. In T. bicolor and T. speciosum, the species with the lowest polyphenolic contents, these cells were mostly located around the vascular bundles. Using Scanning Electron Microscopy, the polyphenolic cells demonstrated a complex cytoarchitecture, and after fixing with glutaraldhyde, the polyphenolic secretion was shown to remain as a single unit or was organized into round droplets. Transmission Electron Microscopy displayed immature plastids from young mesophyll cells containing eletron-dense deposits similar to phenolic substances, suggesting that Theobroma plastids are involved in the synthesis of phenolics.
\end{abstract}

Key words - cotyledon mesophyll cells, polyphenolic cells development, seed, Theobroma

RESUMO - (As células polifenólicas e as suas inter-relações com as células cotiledonares em sete espécies de Theobroma (Sterculiaceae)). A quantidade de células polifenólicas dos cotilédones das espécies de Theobroma variam extensivamente. Os compostos polifenólicos destas células além da função de proteção participam no desenvolvimento do aroma do chocolate. A morfologia das células polifenólicas do mesofilo é descrita e também é analisado o desenvolvimento dos idioblastos em $T$. cacao L., T. subincanum Mart., T. obovatum Klotzsch ex Bernoulli, T. grandiflorum (Willd. ex Spreng.) K. Schum., T. microcarpum Mart., T. bicolor Bonpl. e T. speciosum Willd. ex Spreng. A quantidade de polifenóis totais determinada por espectrofotometria apresentou uma grande variação, cerca de 40 vezes entre T. cacao (variedade forastero). As células polifenólicas apresentam-se transparentes e dispersas pelo mesofilo cotiledonar. Em T. cacao e T. grandiflorum grande número de células estão alinhadas perpendicularmente à borda do mesofilo e apresentam coloração púrpura translúcida. Entretanto, em todas as espécies as células polifenólicas também associam-se ao feixe vascular. Nas espécies T. bicolor e T. speciosum, com baixo conteúdo polifenólico, estão localizadas apenas na região do feixe vascular. À microscopia eletrônica de varredura, as células polifenólicas apresentam uma complexa citoarquitetura e após a fixação em glutaraldeído, a secreção polifenólica exibe um só conteúdo ou fragmenta-se em várias gotas esféricas. À microscopia eletrônica de transmissão aparecem nas células jovens do mesofilo, plastídeos imaturos eletrondensos, semelhantes a substâncias polifenólicas sugerindo que em Theobroma os plastídeos estão envolvidos na síntese de polifenóis.

Palavras-chave - células do mesofilo cotiledonar, desenvolvimento de células fenólicas, semente, Theobroma

\section{Introduction}

Polyphenols are compounds derived from glucose metabolism through the acetate and shikimate pathways.

1. Instituto Adolfo Lutz, Rua São Carlos 720, Vila Industrial, 13035420 Campinas, SP, Brazil.

2. Universidade de São Paulo, Centro de Energia Nuclear na Agricultura, Caixa Postal 96, 13400-970 Piracicaba, SP, Brazil.

3. Universidade Estadual de Campinas, Faculdade de Engenharia de Alimentos, Departamento de Alimentos e Nutrição, Caixa Postal 6121, 13083-862 Campinas, SP, Brazil.

4. Corresponding author: mhmartini@ial.sp.gov.br
Over 8,000 phenolic compounds are known (Bravo 1998). This plurality is associated with the functional diversity observed from cell wall formation up to protection from biotic and abiotic plant stresses (Zaprometov 1992, Hutzler et al. 1998, Kuras et al. 1999). In the cotyledon mesophyll of Theobroma species, the polyphenolic substances from respective idioblast cells are gathered inside large, transparent vacuoles, and Theobroma cacao and T. grandiflorum show even larger vacuoles displaying a translucent purple colouration (Martini 2004). 
Polyphenolic cells are found in the epidermis and subepidermis of the leaves and roots and in the cotyledon mesophyll of the seeds of T. cacao (Biehl et al. 1977, Jalal \& Collin 1977). The seed polyphenolics provide, together with other reserve elements, the flavour and colour to chocolate (Porter et al. 1991) and represent from $12 \%$ to $20 \%$ dw of the defatted seeds (Kim \& Keeney 1984, Wollgast \& Anklam 2000). Epicatechin, pro-anthocyanidins and catechin are the major phenolic compounds (Wollgast \& Anklam 2000).

The health effects of cacao flavonoids were reviewed by Lamuela-Raventós et al. (2001), Keen et al. (2005) and Sies et al. (2005). The bioavailability of these compounds depends on other food constituents and on their interaction with the food matrix (Scalbert et al. 2005, Manach et al. 2005).

The present study of polyphenolic cells was performed after using a series of techniques to prepare the fresh cotyledon mesophylls and also using ordinary microscopic techniques. The objective was to display the morphology and cell characteristics of seven species of Theobroma.

\section{Material and methods}

Seeds of Theobroma cacao L., T. subincanum Mart., T. obovatum Klotzsch ex Bernoulli, T. grandiflorum (Willd. ex Spreng.) K. Schum., T. microcarpum Mart., T. bicolor Bonpl. and T. speciosum Willd. ex Spreng. were obtained from mature fruits from the germplasm collection of the "Comissão Executiva do Plano da Lavoura Cacaueira Ceplac" located in Marituba, PA, Brazil (1 ${ }^{\circ} 12^{\prime}$ S; 49³0’ W).

For each species, 8 to 10 seeds were removed from two mature fruits and a third one starting to mature. The fruits were gathered and sent to the authors by plane in a single week. T. cacao was also received from Itabuna, Bahia (5 fruits). The cotyledons were split and one half microscopically studied whilst the other one was chemically analysed.

One fresh cotyledon mesophyll, normally tightly folded, was immediately immersed in cold phosphate buffer $0.1 \mathrm{M}$, pH 7.1, and carefully unfolded. Using optical microscopy (OM), each cell type still alive could be recognized. Structural cellular enhancement was carried out using Toluidine Blue (TB) at pH 4 or pH 8 (O'Brien \& McCully 1981), as well as with Rhodamine B (RB) and Brilliant Cresyl Blue (BCB) vital dyes (Gahan 1984). In order to obtain permanent samples of the specific seed, the mesophyll of the second cotyledon was fixed in $4 \%$ glutaraldehyde phosphate in $0.1 \mathrm{M}$ buffer, included in methacrylate resin, and prepared for OM, both according to O'Brien \& McCully (1981). Histological routine methods for Scanning Electronic Microscopy (SEM) and Transmission Electronic Microscopy (TEM) were also performed (Harris 1991).
The amount of seed polyphenols was determined by spectrophotometry according to the AOAC International official methods of analyses of (AOAC 1997).

\section{Results and discussion}

The polyphenolic cell contents were almost transparent. The respective polyphenolic synthesis inside these cells varied according to fruit maturity and gradually increased, replenishing the cell volume. These cells could also synthesize proteins, lipids and starch granules and the synthesis decreased as the respective polyphenolic cells matured (Martini et al. 2003). Both Theobroma cacao and T. grandiflorum polyphenolic cells (figures 1-2) displayed the same maturation features described above, but only the polyphenolic cells of these two species developed an intrinsic red translucent colour (Martini 2004). Another feature of T. cacao and T. grandiflorum was the perpendicular orientation of the polyphenolic cells towards the edges of the mesophyll. Finally, a third characteristic common to T. cacao, T. grandiflorum and $T$. obovatum was the feeble adhesion amongst the mesophyll cells. Freshly made sections of the mesophyll of T. obovatum (figure 3) even showed that the round polyphenolic cells were easily separated from vicinal mesophyll cells, a property that might be interesting in cell culture assays.

With respect to the localization, these polyphenolic cells were scattered throughout the parenchymal cells in the seven species and also showed a lengthwise association with the mesophyll vascular system (figure 4). The still alived hyaline polyphenolic cell sections showed a green response under Toluidine Blue at $\mathrm{pH} 4$ (figure 5). Furthemore this figure displays the mucilage from damaged cotyledon cells, which became violet as soon as the fresh cotyledon was sliced (figure 5).

After fixing in glutaraldehyde and carrying out an ordinary histological routine, followed by observation under an OM, figures 6 to 12 show the mesophylls and respective polyphenolic cells of the seven Theobroma species. As demonstrated by Martini (2004) the seed mesophyll was always folded and the pattern of folding varied amongst the seven species. The three most folded mesophylls were that of T. grandiflorum (figure 6), $T$. obovatum (figure 7) and T. subincanum(figure 8); consequently these mesophylls were the thinnest, with a thickness varying from 100 to $150 \mu \mathrm{m}$ (figure 7). The mesophyll polyphenolic cell was frequently in the vicinity of vascular bundles for the seven species. The polyphenolic cells of T. bicolor (figure 9), T. speciosum (figure 10) and T. microcarpum (figure 11) were markedly aligned with the vascular bundles, and it was ubiquitous the mucilage 

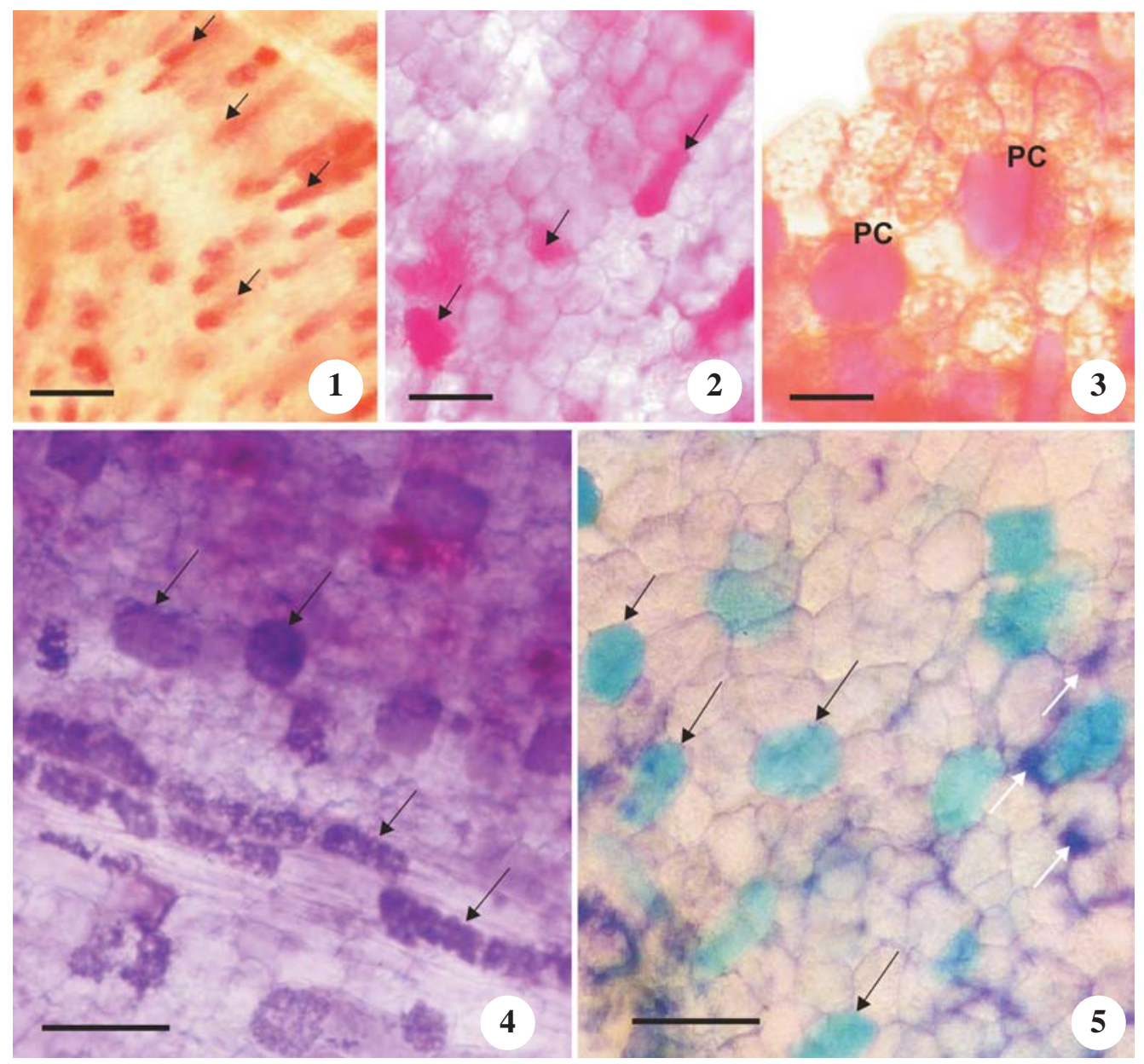

Figures 1-5. Fresh mesophyll sections: 1. Theobroma cacao: the isolated or associated polyphenolic cells display an intrinsic red coloration (arrow). 2. T. grandiflorum: its phenolic cells (arrow) display an intrinsic red colour similar to T. cacao. 3. The T. obovatum mesophyll and its respective polyphenolic cells (PC) are stained with Rhodamine Blue. 4. T. subincanum: Rhodamine Blue, polyphenolic cell rows (arrow). 5. T. subincanum: stained with Toluidine Blue, the intact polyphenolic cells (black arrow) and mucilage (white arrow) became light violet. Bar $=100 \mu \mathrm{m}(1-4) ; 50 \mu \mathrm{m}(2-3.5)$.

inside all the mesophyll cells. In T. speciosum (figure 10) the mucilage leaked out of the mesophyll cells and was restrained into structured pockets as big as $400 \times 300 \mu \mathrm{m}$. This was like intracellular mucilage, metachromatically staining purple with TB at $\mathrm{pH}$ 8. These characteristic $T$. speciosum pockets were always adjacent to polyphenolic cells (Martini 2004). Finally, T. cacao (figure 12) showed another kind of fusion, i.e. fusion amongst the aligned polyphenolic cells. The amount of polyphenols, measured by spectrophotometry, showed a variation of about forty times amongst the seven species (table 1). Even the different $T$. cacao cultivars show a considerable variation in the amount of polyphenols, the T. cacao "Forastero" cultivar showing twice as much polyphenols as the other T. cacao varieties (table 1). Such higher polyphenol contents provide greater astringency to the chocolate.
Table 1. Polyphenols $\left(\mathrm{mg} \mathrm{g}^{-1}\right)$ on a dry, defatted basis from the cotyledons of seven Theobroma species.

\begin{tabular}{lc}
\hline Samples & Polyphenols $^{\mathrm{a}}\left(\mathrm{mg} \mathrm{g}^{-1}\right)$ \\
\hline T. $_{\text {cacao }}{ }^{(\mathrm{b}) *}$ & $132.7 \pm 7.5$ \\
T. $_{\text {cacao }}^{* *}$ & $79.9 \pm 6.1$ \\
T. subincanum & $55.2 \pm 2.8$ \\
T. obovatum & $51.0 \pm 5.0$ \\
T. grandiflorum & $42.7 \pm 2.3$ \\
T. microcarpum & $26.8 \pm 1.1$ \\
T. bicolor & $5.0 \pm 1.2$ \\
T. speciosum & $3.2 \pm 0.5$
\end{tabular}

$\mathrm{a}=$ Values: average \pm standard deviation; $\mathrm{b}=$ seeds of the $T$. cacao forastero variety; $(*=$ forastero variety: dark violet seeds; $* *=$ unknown variety: whitish seeds). 


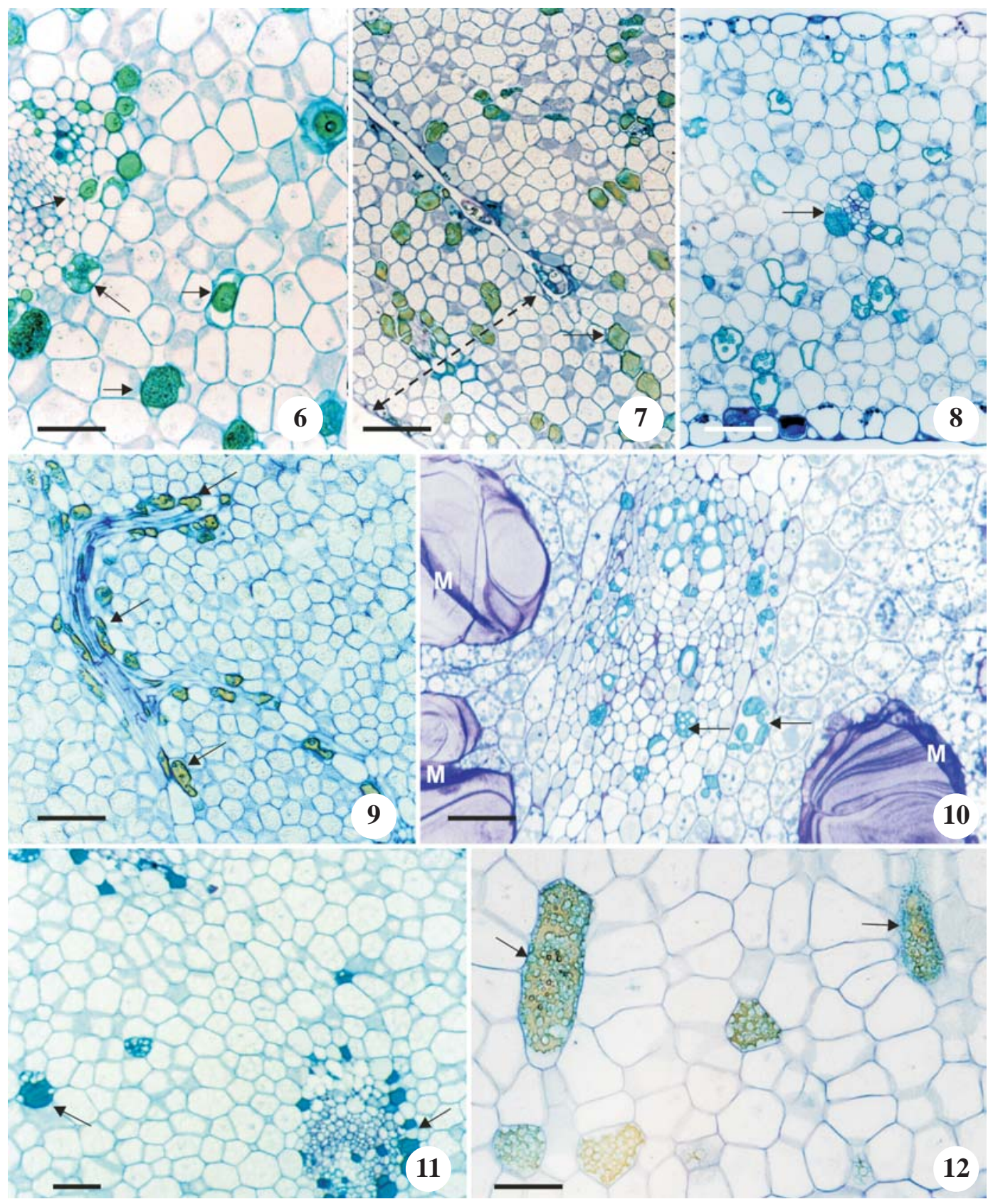

Figures 6-12. Cotyledon mesophylls of the seven species and their respective polyphenolic cells (arrow). 6. Theobroma grandiflorum. 7. T. obovatum ( $\cdots=$ thin mesophyll). 8. T. subincanum. 9. T. bicolor. 10. T. speciosum. 11. T. microcarpum. 12. T. cacao. Sections $6,7,8,9,11,12$ were stained with Toluidine blue at $\mathrm{pH} 4$ and section 10 at $\mathrm{pH}$ 8: the metachromasy at $\mathrm{pH} 4$ is greenish; the metachromasy at $\mathrm{pH} 8$ for the mucilage pockets (M) of the T. speciosum is clear violet. 12. The arrows indicate the variation amongst the fused polyphenolic T. cacao cells. Bar $=100 \mu \mathrm{m}(6,10,12) ; 50 \mu \mathrm{m}(7,8,9,11)$.

Using SEM, the polyphenolic cells were shown to have a complex cytoarchitecture. After fixing the mesophyll with glutaraldhyde, the whole polyphenolic secretion could remain as one (figure 13), but frequently it ruptured and reorganized itself as round droplets, as exemplified by T. microcarpum and T. cacao polyphenolic cells (figures $14,15)$. In both cases, the polyphenolic contents were covered by a visible membrane similar to the one covering the mucilage pockets in T. speciosum (Martini et al. 2003).

As mentioned earlier, the polyphenolic cells of $T$. cacao had a tendency to form cell rows (figure 16). Depending on the degree of maturation of the cell rows, they remained individualized or became associated (figure 15). SEM showed extracelular interconnections 


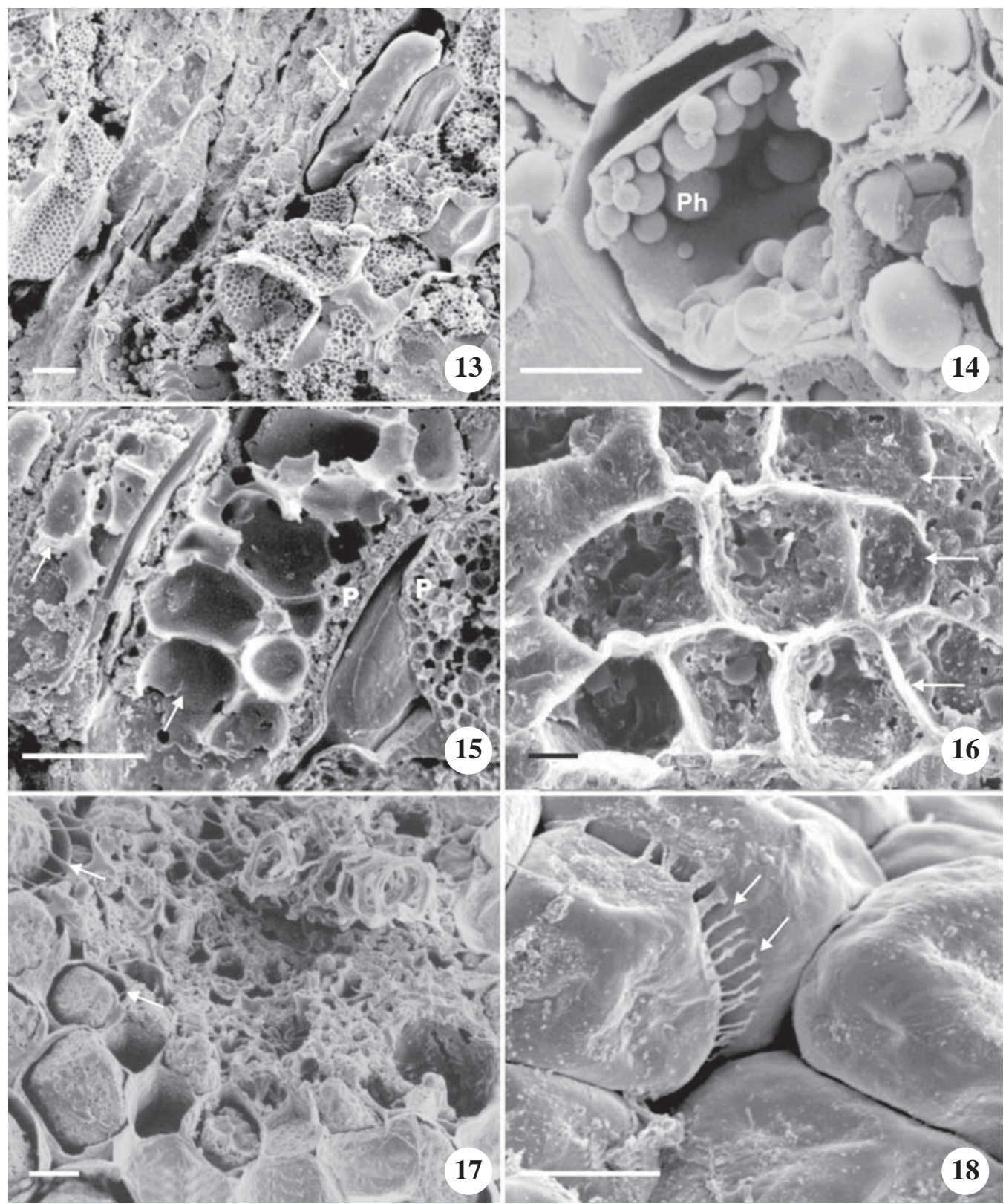

Figures 13-18. SEM: Polyphenolic cell and mucilage: 13. Theobroma cacao; arrow indicating a polyphenolic cell measuring about $50 \mu \mathrm{m}$. 14. T. microcarpum, cell presenting polyphenolic content $(\mathrm{Ph})$ : very frequent fragmentation of the polyphenolic cell contents. 15. T. cacao: two vicinal polyphenolic cells exhibiting polyphenolic contents (arrow). A very thin area of cytoplasm surrounds the polyphenolic contents. Proteins $(\mathrm{P})$ have a spongy appearance when observed by SEM because the fat globules were removed. 16. T. cacao, three rows of polyphenolic cells (arrow), where the contents have been partly removed. 17. T. bicolor, displaying mucilage crossing the cell wall (arrow). 18. T. obovatum: as a rule the mesophylls cells are barely connected, and this feature was especially evident in this species. Bar $=10 \mu \mathrm{m}(13-18)$.

to $T$. bicolor and T. obovatum (figures 17,18 ), already demonstrated by TEM in T. cacao by Martini (2004).

Using TEM (figures 19-22), incipient polyphenolics synthesis was shown in the mesophyll of immature cells (figures 19-21), and this synthesis was concomitant with that of proteins and lipids in the cytosol (figures
19-21). At this early stage plastid bodies containing polyphenolic substances could already be seen (figures 19, 20). Bruce et al. (1994) emphasized the extraordinary intraplastid capacity demonstrated during the early cell stages. According to Alemanno et al. (2003), T. cacao phenolics synthesis may occur in immature seed tissues 


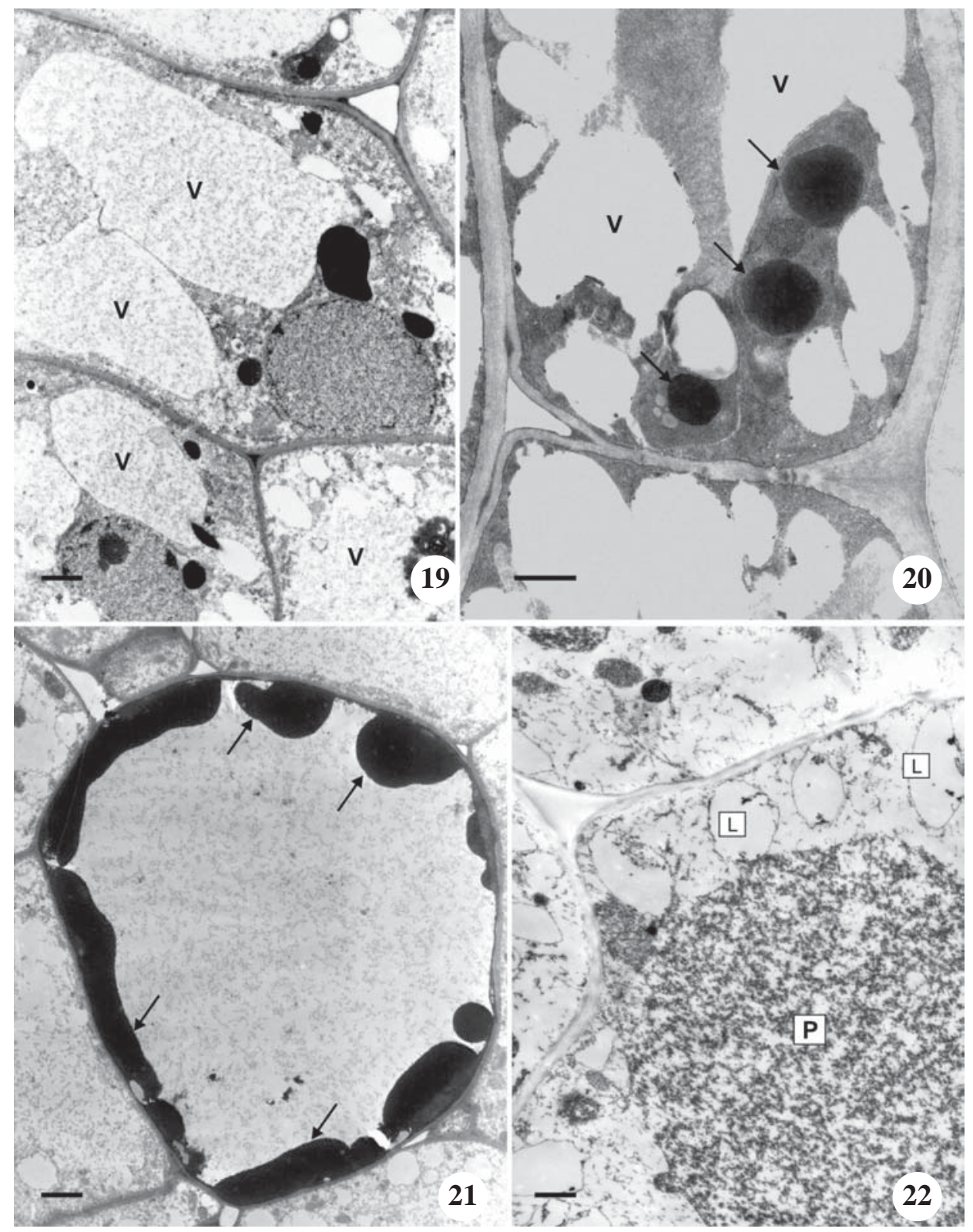

Figures 19-22. TEM: Polyphenolic bodies and lipid and protein synthesis in the cotyledon mesophyll. 19. Theobroma cacao: the beginning of polyphenol synthesis in the mesophyll idioblasts and cytoplasm vacuoles (V). 20. T. subincanum: three intraplastid bodies (arrow). 21. T. cacao presents polyphenol vesicles adhered to the plasmatic membrane (arrow). 22. T. speciosum: $(\mathrm{P})$ reserve protein prevailing over other synthesis and also lipid bodies (L). Bar $=1 \mu \mathrm{m}(19-21) ; 2 \mu \mathrm{m}(22)$.

as a response to stressful conditions, owing to antioxidant capacity of these substances. However part of the polyphenol synthesis is correlated with the endoplasmic reticulum. According to Rühl \& Biehl (1989) and Rühl \& Dambroth (1989), there is a trend to consider polyphenol synthesis as originated from the endoplasmic reticulum. This paper (figure 20) shows several plastid bodies containing homogeneous substances with aspect and density similar to those of polyphenolic substances.
Figure 21 (T. cacao) shows a polyphenolic cell at a more advanced stage. The vesicles of polyphenolic substances have now occupied the periphery of the cell, as also demonstrated by SEM. During the preparation of fresh mesophyll tissue for SEM and TEM studies, the polyphenolic vesicle could eventually break, giving rise to many round vesicles (figures 14, 21). As mentioned above, during cell maturation, in the seven species, the polyphenolic cells also synthesized a rather small quantity of lipid, protein and starch (figure 22). 
Acknowledgments - We would like to thank the technical support of Yara Fagnani Honório.

\section{References}

ALEMANNO, L., RAMOS, T., GARGADENEC, A., ANDARY, C. \& FERRIERE, N. 2003. Localization and identification of phenolic compounds in Theobroma cacao L. somatic embryogenesis. Annals of Botany 92:613-623.

AOAC. 1997. Official methods of analysis of AOAC International (P. Cunniff, ed.) AOAC, Gaithersburg, v.1-2.

BRUCE, A., BRAY, D., LEWIS, J., RAFF, M., ROBERTS, K., WATSON, J.D. 1994. Molecular biology of the cell. $3^{\text {rd }}$ ed. Garland Publishing, Inc. New York \& London.

BIEHL, B., PASSERN, U. \& PASSERN, D. 1977. Subcellular structures in fermenting cocoa beans. Effect of aeration and temperature during seed and fragment incubation. Journal of the Science of Food and Agriculture 28:41-52.

BRAVO, L. 1998. Polyphenols: chemistry, dietary sources, metabolism, and nutritional significance. Nutrition Reviews 56:317-333.

GAHAN, P.B. 1984. Plant histochemistry and cytochemistry: an introdution. Academic Press, London.

HARRIS, J.R. 1991. Electron microscopy in biology: a practical approach. Oxford University Press, New York.

HUTZLER, P., FISCHBACH, R., HELLER, W., JUNGBLUT, T.P., REUBER, S., SCHMITZ, R., VEIT, M., WEISSENBÖCK, G. \& SCHNITZLER, J.P. 1998. Tissue localization of phenolic compounds in plants by confocal laser scanning microscopy. Journal of Experimental Botany 49:953-96.

JALAL, M.A.F. \& COLLIN, H.A. 1977. Polyphenols of mature plant, seedling and tissue cultures of Theobroma cacao. Phytochemistry 116:1377-1380.

KEEN, C.L., HOLT, R.R., OTEIZA, I., FRAGA, C.G. \& SCHMITZ, H.H. 2005. Cocoa antioxidants and cardiovascular health. American Journal of Clinical Nutrition 81:2985-3035.

KIM, H. \& KEENEY, P.G. 1984. Epicatechin content in fermented and unfermented cocoa beans. Journal of Food Science 49:1090-1092.

KURAS, M., WRONKA, M., LYNCH, J.M. \& ZOBEL, A.M. 1999. Cytochemical localization of phenolic compounds in columella cells of the root cap in seeds of Brassica napus - changes in the localization of phenolic compounds during germination. Annals of Botany 84:135-143.
LAMUELA-RAVENTÓS, R.M., ANDRES-LACUEVA, C. \& PERMANYER, I.P.N. 2001. More antioxidants in cocoa. Journal of Nutrition 131:834-835.

MANACH, C., WILliAMSON, G., MORAND, C., SCALBERT, A. \& REMÉSY, C. 2005. Bioavailability and bioefficacy of polyphenols in humans. I. Review of 97 bioavailability studies. Dietary polyphenols and health: proceedings fo the $1^{\text {st }}$ International Conference on Polyphenols and Health. American Journal of Clinical Nutrition 81:2305-2425.

MARTINI, M.H. 2004. Caracterização das sementes de seis espécies de Theobroma em relação ao Theobroma cacao L. Tese de doutorado, Universidade Estadual de Campinas, Campinas.

MARTINI, M.H., LENCI, C.G. \& TAVARES, D.Q. 2003. Mucilage pockets in cotiledon tissue of Theobroma speciosum. Acta Microscopica 1:65-69.

O’BRIEN, T.P. \& MCCULLY, M.E. 1981.The study of plant structure principles and selected methods. Termarcarphy Pty. Ltd., Melbourne.

PORTER, L.J., MA, Z. \& CHAN, B.G. 1991. Cacao procyanidins: major flavanoids and identification of some minor metabolites. Phytochemistry 30:1657-1663.

RÜHL, G. \& BIEHL, B. 1989. Investigations in the causes of sensitivity to cold and water stress of tropical seeds, represented by cacao seeds. IV. Ultrastructure of the cotyledonary storage parenchyma cells of desiccating cacao seeds. Landbauforschung Völkenrode 39:15-27.

RÜHL, G. \& DAMBROTH, M. 1989. Investigations in the causes of sensitivity to cold and water stress of tropical seeds, represented by cacao seeds. III. Ultrastructure of the parenchyma cells in radicles of desiccating cacao seeds. Landbauforschung Völkenrode 39:1-15.

SCALBERT, A., JOHNSON, I.T. \& SALTMARSH, N. 2005. Polyphenols: antioxidants and beyond. American Journal of Clinical Nutrition 81:2155-2175.

SIES, H., SCHEVE, T., HEISS, C. \& KELM, N. 2005. Cocoa polyphenols and inflammatory mediators. American Journal of Clinical Nutrition 81:3045-3125.

WOLLGAST, J. \& ANKLAM, E. 2000. Review on polyphenols in Theobroma cacao: changes in composition during the manufacture of chocolate and methodology for identification and quantification. Food Research International 33:423-447.

ZAPROMETOV, M.N. 1992. On the functional role of phenolic compounds in plants. Soviet Plant Physiology 39:802-809. 